Article

\title{
Short Communication: Oral Administration of Heat-killed Lactobacillus brevis KB290 in Combination with Retinoic Acid Provides Protection against Influenza Virus Infection in Mice
}

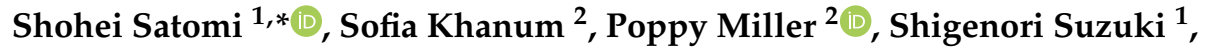 \\ Hiroyuki Suganuma ${ }^{1}\left(\mathbb{D}\right.$, Axel Heiser ${ }^{2}(\mathbb{D})$ and Sandeep K Gupta ${ }^{2, *(1)}$ \\ 1 Department of Nature \& Wellness Research, Innovation Division, KAGOME CO., LTD., 17 Nishitomiyama, \\ Nasushiobara, Tochigi 329-2762, Japan; Shigenori_Suzuki@kagome.co.jp (S.S.); \\ Hiroyuki_Suganuma@kagome.co.jp (H.S.) \\ 2 AgResearch Ltd., Hopkirk Research Institute, Grasslands Research Centre, Private Bag 11008, \\ Palmerston North 4442, New Zealand; Sofia.Khanum@agresearch.co.nz (S.K.); \\ Poppy.Miller@agresearch.co.nz (P.M.); Axel.Heiser@agresearch.co.nz (A.H.) \\ * Correspondence: Shohei_Satomi@kagome.co.jp (S.S.); Sandeep.Gupta@agresearch.co.nz (S.K.G.); \\ Tel.: +81-80-8132-3813 (S.S.); +64-06351-8697 (S.K.G.)
}

Received: 4 August 2020; Accepted: 21 September 2020; Published: 24 September 2020

check for updates

\begin{abstract}
Influenza virus type A (IAV) is a seasonal acute respiratory disease virus with severe symptoms, and an effective preventive measure is required. Despite many reports describing the potentially protective effects of lactic acid bacteria, few studies have investigated the effects of nutritional supplement combinations. This study reports the effect of the combined intake of heat-killed Lactobacillus brevis KB290 (KB290) and vitamin A (VA) on mice challenged with a sublethal dose of IAV. For 2 weeks, five groups of mice were fed either placebo, KB290, VA, or a combination of KB290 and VA (KB290+VA). After subsequent IAV challenge, bodyweight and general health were monitored for up to 2 weeks. Viral titres were determined in the lungs of animal subgroups euthanised at days 3, 7, and 14 after IAV challenge. A significant loss was observed in the bodyweights of IAV-infected animals from day 1 post-IAV challenge, whereas the mice fed KB290+VA did not lose any weight after IAV infection, indicating successful protection from the infection. Additionally, mice in the KB290+VA group showed the highest reduction in lung viral titres. In conclusion, the combination of KB290 and VA could be a useful food supplement relevant for protection against seasonal influenza virus infection in humans.
\end{abstract}

Keywords: influenza virus; Lactobacillus; retinoic acid; combination effects

\section{Introduction}

Seasonal influenza is a significant threat to human health that causes high levels of morbidity and mortality. Annual influenza epidemics are estimated to result in about 3 to 5 million cases of severe illness worldwide and about 290,000 to 650,000 respiratory deaths [1]. Clinical symptoms caused by influenza virus type A (IAV) infection often become severe in elderly individuals and infants as a result of a poor or weakened immune system [2,3]. Vaccination against IAV has been employed successfully, but this approach reduces the risk of medically attended influenza virus infection by only approximately 50\%, and its effectiveness depends on the season, setting, and population subgroup [1]. Therefore, it is desirable to discover alternative strategies such as probiotics and food supplements that strengthen the innate and adaptive immune systems and promote protection to IAV infection. 
Lactic acid bacteria (LAB) are historically important because of their utility in food preservation and fermentation; they can exert immunomodulatory effects in the respiratory tract and protect the host against IAV infection [4,5]. Previous studies have reported a reduction in IAV-induced weight loss in mice treated with $\mathrm{LAB}[4,6-17]$. However, safety remains a major concern with the use of live microorganisms as probiotics because the potential risks include systemic infection, antibiotic resistance gene acquisition, and gut colonisation interference in neonates [18-21]. Recently, the use of heat-killed microorganisms as probiotics has attracted attention, and several studies have demonstrated the effects of such bacteria in modulating immune responses and enhancing the intestinal barrier function [22-24]. Moreover, it has been reported that both live and heat-killed lactobacillus strains show similar immune-modulatory properties [25-28], suggesting that heat-killed LAB could be used effectively without the safety concerns associated with the use of live LAB.

Lactobacillus brevis KB290 (KB290) is a plant-derived microorganism isolated from "Suguki", a traditional pickle made in Kyoto, Japan. KB290 has been reported to be safe for human consumption, tolerant to gastrointestinal juices, and capable of improving human bowel function [29], as well as useful for early intervention in irritable bowel syndrome [30]. Furthermore, the KB290 ingestion has been shown to enhance interferon (IFN)- $\alpha$ production in humans [31]. It was previously reported that orally administered KB290 enhanced the cell-mediated cytotoxic activity of splenocytes, possibly via the activation of natural killer (NK) cells and/or $\mathrm{CD}^{+}$cytotoxic $\mathrm{T}$ cells [32], which alleviated clinical symptoms following influenza virus infection in mice [14], and reduced the incidence of influenza infection among schoolchildren [33].

Despite the large body of work describing the potentially protective effects of LAB alone, only a few studies have investigated the ability of nutritional supplement combinations to increase host protection against influenza. Vitamin A (VA) supplementation has been reported to modulate the intestinal cytokine response during viral infection and to contribute to both innate and adaptive immune responses [34-37]. Retinoic acid, a metabolite of VA, has been shown to promote mucosal immune responses by regulating gut cells [38-40]. In addition, retinoic acid has also been found to modulate the expression of retinoic acid-inducible gene-I (RIG-I), a viral pattern recognition receptor that is expressed during viral infection [41,42]. Furthermore, the oral administration of retinoic acid to mice fed a VA-deficient diet was reported to restore mucosal immunoglobulin A (IgA) responses to intranasal influenza virus vaccines [43].

Here, we provide evidence that oral coadministration of heat-killed KB290 and VA can induce protection against IAV infection in mice. To our knowledge, this is the first study to demonstrate the effects of a food nutrient combination on IAV infection.

\section{Materials and Methods}

\subsection{Mice}

Specific pathogen-free 7- to 8-week-old, female BALB/c mice were supplied by the AgResearch Small Animal Facility (Hamilton, New Zealand), and the study was conducted at AgResearch's Ulyatt-Reid Facility (Palmerston North, New Zealand). Mice were housed in groups of 3-4 per cage in plastic cages on a 12-h light/dark cycle and fed mouse pellets

(Prolab ${ }^{\circledR}$ RMH 1800; LabDiet, Richmond, IN, USA) and tap water (autoclaved under pressure at $121^{\circ} \mathrm{C}$ for $15 \mathrm{~min}$ ) ad libitum. The room temperature was kept at $21^{\circ} \mathrm{C}$, and the humidity was kept at $50 \%$. All procedures involving the experimental use of animals were approved by the Grasslands Animal Ethics Committee, Palmerston North, New Zealand (approval number 14542).

\subsection{Feeding Solution Preparation}

KB290 was deposited as strain L. brevis JCM 17,312 in the Japan Collection of Microorganisms and has been maintained at the Research Institute, KAGOME CO., LTD. (Tochigi, Japan). Heat-killed and lyophilised powder of KB290 was used in the animal experiments. KB290 was suspended in 
phosphate-buffered saline (PBS) at a concentration of $5.41 \times 10^{10}$ cells per $\mathrm{mL}$ immediately before use. Retinoic acid (Sigma, St. Louis, MO, USA) was suspended in food-grade canola oil (Pam's Canola Oil, Made in Malaysia, purchased at Countdown, Palmerston North, New Zealand) at a concentration of $20 \mathrm{mg} / \mathrm{mL}$.

\subsection{Feeding Intervention}

Mice were gavaged using 16ga polyurethane feeding tubes (Instech Laboratories, Plymouth Meeting, PA, USA) with $200 \mu \mathrm{L}$ of feeding solution per mouse per day for 14 consecutive days prior to IAV challenge. Five groups containing 30 mice each received feeding solutions as follows: Normal group received placebo ( $185 \mu \mathrm{L}$ of PBS $+15 \mu \mathrm{L}$ of canola oil), the Control group also received placebo (185 $\mu \mathrm{L}$ of PBS $+15 \mu \mathrm{L}$ of canola oil), VA group received $300 \mu \mathrm{g}$ of retinoic acid (in $15 \mu \mathrm{L}$ of canola oil $+185 \mu \mathrm{L}$ of PBS), KB290 group received $10^{10} \mathrm{~KB} 290$ cells (in $185 \mu \mathrm{L}$ of PBS $+15 \mu \mathrm{L}$ of canola oil), and KB290+VA group received $10^{10} \mathrm{~KB} 290$ cells (in $185 \mu \mathrm{L}$ of PBS) plus $300 \mu \mathrm{g}$ of retinoic acid (in $15 \mu \mathrm{L}$ of canola oil).

\subsection{Influenza Virus}

The challenge virus was a mouse-adapted strain of IAV, A/PR/8/34 (H1N1), prepared for a previous study by our group [14]. Briefly, the virus was propagated in the allantoic cavity of 10-day-old embryonated hen eggs. The allantoic fluid was harvested 3 days post-inoculation. The allantoic fluid supernatant was separated from the debris by centrifugation for $5 \mathrm{~min}$ at $500 \times g$ at $4{ }^{\circ} \mathrm{C}$ in a Heraeus Multifuge 3 S-R (ThermoFisher Scientific, Osterode am Harz, Germany); the resulting viral stocks were stored at $-80{ }^{\circ} \mathrm{C}$ without the addition of preservatives. The $50 \%$ tissue culture infectious dose $\left(\mathrm{TCID}_{50}\right)$ of the viral stock was determined to be $10^{6.75} / \mathrm{mL}$ by using the chicken red blood cell hemagglutination endpoint method in Madin-Darby canine kidney (MDCK) cells $[44,45]$. The $\mathrm{LD}_{50}(50 \%$ mouse lethal dose) for the intranasally inoculated virus was determined to be $2 \times \mathrm{TCID}_{50}$.

\subsection{IAV Challenge}

On the day after the continuous 14-day feeding period ended, all mice in four of the groups (Control, VA, KB290, and KB290+VA) were challenged with a sublethal dose of IAV. The Normal group was left unchallenged and housed in a separate room to prevent unintentional exposure to IAV. For the viral challenge, the mice were lightly anaesthetised by using a subcutaneous injection of $200 \mu \mathrm{L}$ of ketamine/medetomidine containing $2.53 \mathrm{mg} / \mathrm{mL}$ ketamine (Ketamine injection; Parnell Laboratories NZ Ltd., Auckland, New Zealand; Product no. RVM A005925) and $0.03 \mathrm{mg} / \mathrm{mL}$ medetomidine hydrochloride (Domitor; Zoetis NZ, Auckland, New Zealand; Product no: RVM A06177). Anaesthetised mice were challenged intranasally with IAV by applying $10 \mu \mathrm{L}$ of IAV in PBS per nostril (IAV concentration of $0.5 \times \mathrm{LD}_{50}$ per $20 \mu \mathrm{L}$ of PBS). After challenge, the mice were placed on a heat-pad $\left(39^{\circ} \mathrm{C}\right.$; Kent Scientific, Torrington, CT, USA) to maintain body temperature, and the anaesthesia was reversed by an injection of $100 \mu \mathrm{L}$ of atipamezole hydrochloride $(2.5 \mathrm{mg} / \mathrm{mL}$ Atipamezole; Zoetis NZ; Product no: RVM A006178).

\subsection{Bodyweight, Body Temperature, and General Health Score}

During the 14-day feeding period, mouse bodyweights were recorded every second day. After the IAV challenge, this measurement was recorded daily. Weight gain and loss were assessed using electronic scales (Sartorius, Göttingen, Germany). Animal welfare considerations mandated that mice who lost more than $20 \%$ of their bodyweight were to be euthanised by the method described below.

Body temperature was measured using a "No Touch + Forehead" thermometer (Braun, Kronberg im Taunus, Germany) using the method previously described and validated by Mei et al. [46]. The general health status (GHS) was assessed by using a five-point scale modified from Kawase et al. [47] to include signs of respiratory disease: 
Score 5: The mouse is bright-eyed and alert, has a smooth coat with a sheen, responds to a stimulus, and shows interest in its environment. It has a normal breathing rate.

Score 4: Its fur is slightly ruffled with a loss of sheen in the coat, but the mouse remains alert and active. There is evidence of nasal irritation (intermittent nose rubbing/whisker twitch), but the mouse has a normal breathing rate.

Score 3: Its fur is noticeably ruffled, clumps have formed in part of the coat, and the mouse is less alert or active and less interested in its environment. The mouse is sneezing or coughing and continually rubbing its nose.

Score 2: The mouse is hunched over and sleepy, showing little interest in its environment, and its fur is clumped. The mouse is panting or has an audible "wet" breathing sound.

Score 1: The mouse is hunched over and sleepy, its fur has a "bottle brush" appearance (sticking out); the mouse is unreactive to environmental stimuli and its body and paws feel cold to the touch. The mouse has progressed from panting/hyperventilating to exhibiting a very slow respiration rate (gasping) and has an audible "wet" breathing sound.

\subsection{Viral Titre}

Of the 30 mice in each group, 10 mice were euthanised for post-mortem examination on each of the following post-IAV infection days: day 3, day 7, and day 14. Mice were euthanised by using $\mathrm{CO}_{2}$ inhalation and cervical dislocation. Euthanised mice were dissected, and their lungs were collected for viral titre analysis. The left lungs were transferred into $1.5-\mathrm{mL}$ cryotubes, snap-frozen in liquid nitrogen, and transferred within $6 \mathrm{~h}$ to a freezer set at $-80{ }^{\circ} \mathrm{C}$ for storage. The snap-frozen left lungs were later thawed and homogenised using a mixture of Zirconium beads, consisting of $0.5 \mathrm{~g}$ of 1-mm beads (Biospec Products, Bartlesville, OK, USA) and seven to eight 3-mm beads (Benchmark Scientific, Sayreville, NJ, USA). Homogenisation was performed in PBS supplemented with EDTA-free $1 \times$ protease inhibitor (Sigma, St. Louis, MO, USA), $100 \mathrm{U} / \mathrm{mL}$ penicillin, and $100 \mu \mathrm{g} / \mathrm{mL}$ streptomycin (Life Technologies, Auckland, New Zealand) using a TissueLyser II (Qiagen, Hilden, Germany) homogeniser set at $30 \mathrm{~Hz}$ for $5 \mathrm{~min}[48,49]$.

The titre of IAV in the supernatants from lung homogenates was determined by using the chicken red blood cell hemagglutination endpoint method in MDCK cells as described above. The value of the IAV titre was normalised against the total protein content of the sample and is expressed as the $\log _{10}\left(\mathrm{TCID}_{50}\right)$. Total protein was quantified in clarified lung homogenates by using a BCA protein assay kit in accordance with the manufacturer's instructions (ThermoFisher Scientific, Auckland, New Zealand).

\subsection{Statistical Analysis}

\subsubsection{Bodyweight Analysis}

A generalized additive mixed-effects model (gam model from R package mgcv) [50] was fitted to the observed weights with the following covariates: fixed effects for the initial weight (weight when challenged with IAV) and treatment group; a spline for the time effect for each treatment; and random intercepts for each mouse ID and cage. The spline allowed the time effect to be a flexible shape, driven by the data. Estimated marginal mean (emm) curves were calculated using the R package emmeans [51]. Estimated marginal means were calculated by creating a grid of predicted weights for all animals at all times (using the mean initial weight) and averaging the resulting predictions within group and time. This processadjusted for the data imbalance caused by killing animals on days 3 and 7 for post-mortems (as it predicted what their weights would have been had they not been killed) and for the differing mean initial weights for animals in each group and time. Therefore, the emms provided unbiased comparisons between treatments. In general, raw means and emms are identical only when the data are fully balanced and no continuous covariates (e.g., initial weight) are used. 
Pairwise comparisons between treatments were reported for each sampled time and the resulting $p$-values were adjusted using Benjamini and Hochberg's (BH) $p$-value adjustment [52].

\subsubsection{Viral Titre}

The normalised $\log _{10}\left(\mathrm{TCID}_{50}\right)$ viral titres were compared using pairwise permutation t-tests $[53,54]$. The data were not normally distributed, therefore a permutation t-test (pairwise.perm.t.test) was used from the RVAideMemoire R [55]. The permutation t-test compares the observed difference in mean for the two groups to an empirical null distribution.

BH $p$-value adjustment [52] was applied to the $p$-values from all pairwise comparisons; statements of significant differences are based on $p$-values of $<0.05$ and are presented as the mean \pm SEM unless indicated otherwise. Treatment group data were compared with the Normal and Control group data on day 3.

A total of three mice needed to be euthanised during the study because of animal welfare considerations. One mouse from the day 7 PM subgroup of the Control group was euthanised because of a non-study-related injury at day 1 post-IAV challenge, so this subgroup had nine mice for all measurements, and this was considered as a randomly missing data point for statistical analyses. Two mice were euthanised at day 11 post-IAV challenge from the day 14 PM subgroup of the Control group because these mice lost more than $20 \%$ of their bodyweight. This was likely a result of the IAV challenge. However, the lungs were retrieved from both animals, so the viral titres in this group were still measured from 10 animals as planned. The bodyweights for these two mice were still included in the bodyweight statistical analyses and were treated as day-14 samples.

\section{Results}

\subsection{Bodyweight, General Health Score, and Body Temperature Changes}

To examine the effect of orally administered KB290 and VA in combination or alone, the bodyweight, general health score (GHS), and body temperature of the animals were recorded for 2 weeks before and after IAV challenge.

Significant differences in mouse bodyweights among groups were observed from day 1 for several treatments and day 7 for all treatments except Normal and KB290+VA after IAV challenge (Figure 1). The animals in the IAV-infected Control group had significant bodyweight loss from day 1 to 14 after IAV challenge compared with those in the non-infected Normal group, suggesting the establishment of IAV infection in these animals. The bodyweight loss in the KB290+VA group animals was significantly lower than that in the Control group, from all days after IAV challenge. In addition, no differences in mice bodyweight were observed between the KB290+VA group and the Normal group for any period post IAV challenge except for day 13, indicating that KB290+VA-fed mice maintained their bodyweight after IAV infection similarly to the uninfected mice. Furthermore, the bodyweight loss in the VA and KB290 groups were also significantly higher to the Normal group between day 7 and day 12 and between day 1 and day 14, respectively. The bodyweight loss of the VA group was significantly lower compared with that of the Control group for all days but was significantly higher compared with that of the KB290+VA group between day 6 and day 14 post-IAV-challenge. The bodyweight loss of the KB290 group was significantly lower compared with that of the Control group between day 3 and day 12 but was significantly higher compared with that of the KB290+VA group for all days after IAV challenge.

Some non-significant differences were observed in the GHS of animals in the Control and KB290 groups after IAV challenge. The GHS values for the animals in the Control group trended lower than those for the KB290 group mice (data not shown). No differences in the GHS after IAV challenge were observed between any other groups. In addition, no differences were observed in the body temperatures of the animals among any of the treatment groups (data not shown). 

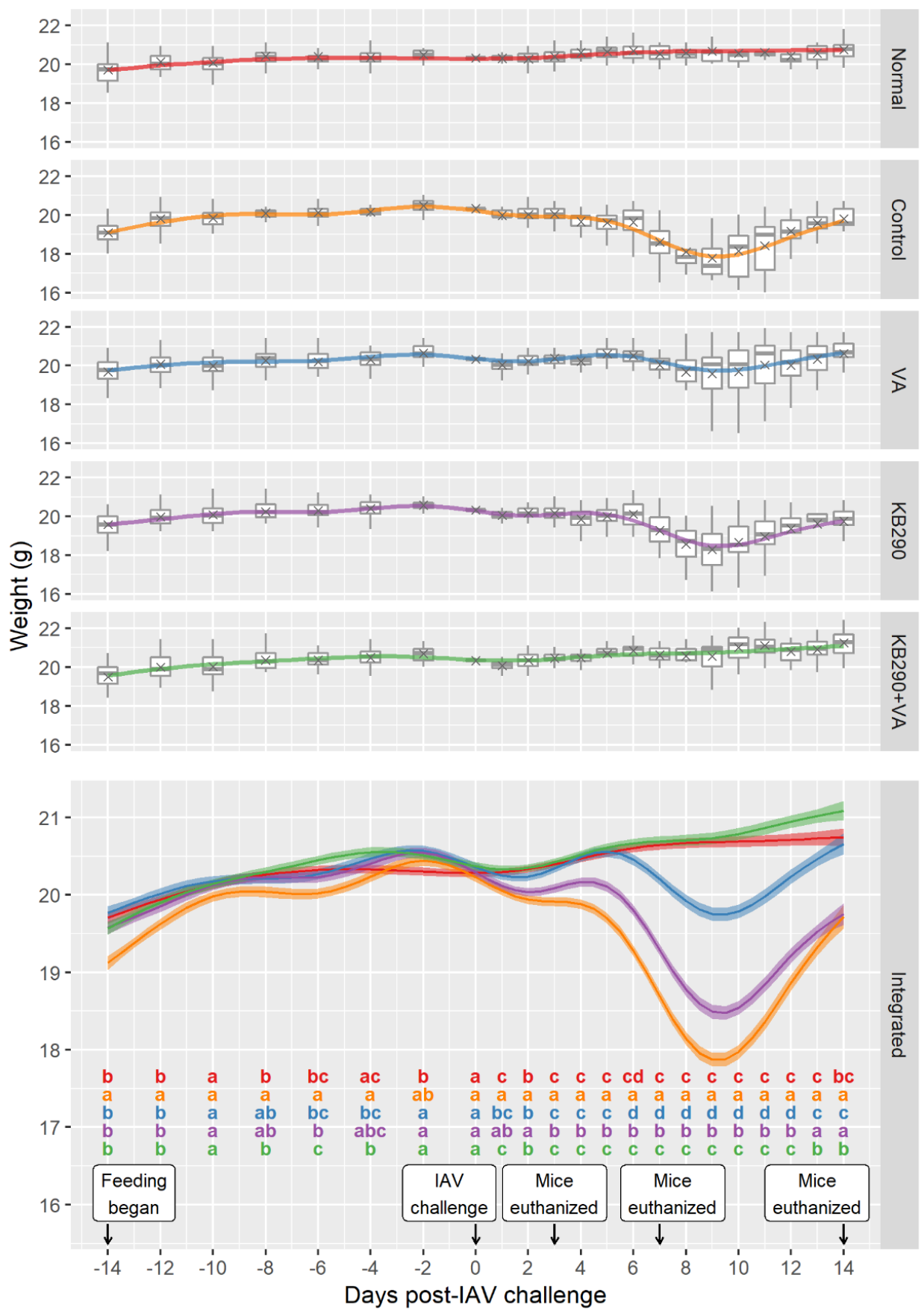

Figure 1. Bodyweights of mice with each treatment before and after Influenza virus type A (IAV) challenge. The estimated marginal mean curves (coloured by treatment) show bodyweight changes over time for a mouse of the average initial weight. The observed data were adjusted for initial weight by subtracting their individual initial weight and adding on the observed mean initial weight. The adjusted weights were plotted as grey boxplots with the mean adjusted weight at each time shown using a grey cross. Pairwise comparisons between the treatment groups were conducted at each observation time. The treatments are significantly different if they do not share a letter (a, b, c, and d) within each time (significance cut-off was 0.05 after using the $\mathrm{BH} p$-value adjustment). The uncertainty ribbon on the combined plot shows the mean $\pm \mathrm{SE}$ (standard error). Each group initially included 30 mice, 10 of which were euthanised after weighing on each of the following days: 3,7 , and 14 post-IAV challenge. 
Overall, the result of bodyweight change suggests that the synergistic effect of combined feeding of KB290 and VA to mice before influenza infection resulted in better health status compared with mice fed KB290 or VA alone.

\subsection{Viral Titre}

On day 3 post-IAV challenge, the lung virus titres in the non-infected Normal and IAV-infected Control groups were $0 \pm 0 \log _{10} \mathrm{TCID}_{50}($ mean $\pm \mathrm{SEM})$ and $0.966 \pm 0.321 \log _{10} \mathrm{TCID}_{50}($ mean $\pm \mathrm{SEM})$, respectively; and were found to be significantly different $(p=0.002)$ (Figure 2$)$.

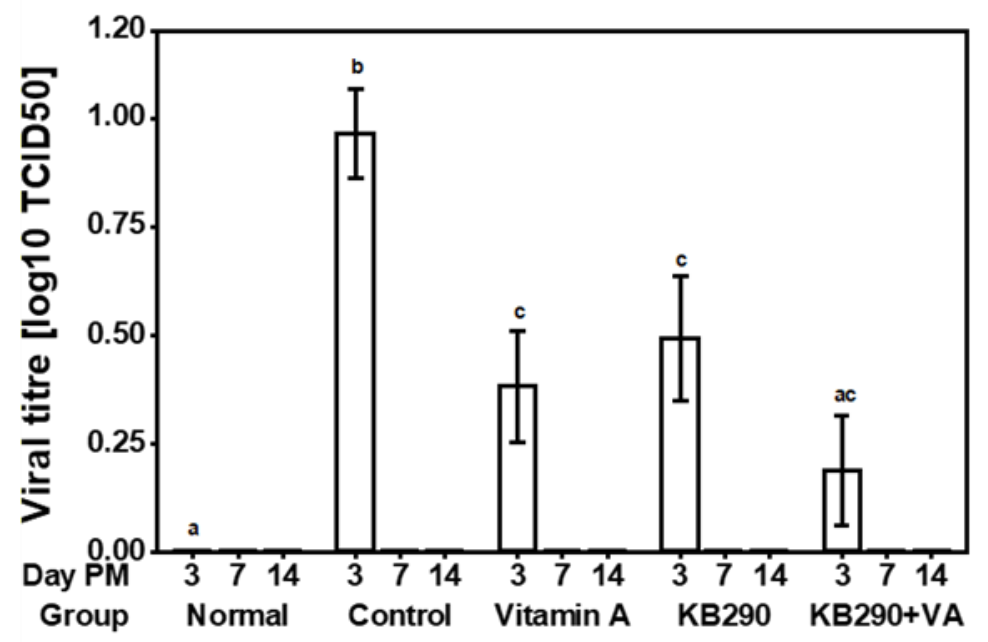

Figure 2. IAV virus titres in murine lungs. Viral titres in the lungs, presented as the $\mathrm{TCID}_{50}(50 \%$ tissue culture infectious dose). This measurement is shown for the five treatment groups at days 3, 7, and 14 post-IAV challenge $(n=10)$. Different letters $(a, b$, and $c)$ indicate significant differences $(p<0.05$, using the $\mathrm{BH}$ p-value adjustment) between the groups on day 3 .

Significantly lower viral titres were observed in lungs of the VA $(p=0.01)$ and KB290 $(p=0.04)$ fed mice compared to the Control group, but these viral tires were significantly higher for the VA $(p=0.05)$ and KB290 ( $p=0.03$ ) groups compared to the Normal group on day 3. Mice in the KB290+VA group showed the highest reduction in lung viral titre compared with the Control group $(p=0.01)$, but no significant difference was observed in viral titre compared to the Normal group ( $p=0.47)$. No virus was detected in the lungs of the mice in any of the groups at days 7 and 14 post-IAV challenge.

\section{Discussion}

Here, we found that the ingestion of a combination of heat-killed KB290 and VA suppressed bodyweight loss and reduced the lung viral titre in mice challenged with a sublethal dose of IAV. Challenging mice with lethal doses of IAV results in markedly different immunopathology compared with challenging them with sublethal doses [56-60]. Sublethal infection with IAV is physiologically relevant because it can closely mimic seasonal influenza infection in humans. In this study, the viral loads can be detected only after $72 \mathrm{~h}$ in mice infected with a sublethal dose of IAV were consistent with previous findings, indicating that mild IAV infection was established in these animals $[60,61]$. We demonstrated that, after infection with a sublethal dose of IAV, mice pre-treated with a combination of heat-killed KB290 and VA had a significantly lower viral load. A reduction in influenza virus in the lungs has been reported as a result of consuming other Lactobacilli, namely L. acidophilus [62], L. casei [63], L. delbrueckii [64], L. gasseri [6,13], L. rhamnosus [65], and L. plantarum [4,10].

Infection with a lethal dose of influenza virus results in an overwhelming release of proinflammatory cytokines and severe bodyweight loss of up to $35 \%$, causing high mortality. Sublethal influenza virus doses have resulted in bodyweight losses of up to $20 \%$ and lower mortality compared with 
lethal doses [56,59]. To simulate naturally occurring influenza virus infections in humans, this study investigated mice challenged with a sublethal dose of IAV. The observed bodyweight losses in the IAV-infected and untreated groups were comparable with those of a previously published report [56]. Feeding of VA by mice prior to IAV challenge led to a marked reduction in bodyweight loss, and feeding of KB290+VA completely prevented IAV infection-induced bodyweight loss. A reduction in bodyweight loss after treating mice with various LAB species, such as live L. brevis KB290 [14], L. bulgaricus [17], L. gasseri [6,13], L. paracasei [15], L. pentosus [8], L. plantarum [4,7,10-12,16], and L. rhamnosus [9], has been reported previously. A complete maintenance of bodyweight despite IAV infection, as observed in this study, has so far been reported only once after an intranasal pre-treatment of mice with heat-killed L. casei [63]. Focusing on the KB290 strain, the present study showed that heat-killed KB290 resulted in suppressing the bodyweight loss in IAV-challenged mice. This finding was in agreement with a previous report, which demonstrated that live KB290 can reduce the influence of IAV in mice [14]. In addition, both live and heat-killed KB290 have been shown to enhance cell-mediated cytotoxic activity in mice [66]. Taken together, these findings suggest that both live and heat-killed forms of KB290, could be effective in providing protection against IAV infection by possibly enhancing the function of immune cells.

The mechanisms by which feeding of a combination of heat-killed KB290 and VA suppressed IAV infection are not clear. Our previous report showed that live KB290 induced IFN- $\alpha$ and IgA in the mice challenged with IAV [14]. In addition, retinoic acid has been reported to be related to RIG-I-mediated production of IFN- $\alpha$ [41,42] and IgA [43]. Compared with the intake of VA or KB290 alone, their combined administration strongly suppressed influenza infection, possibly by improving the local immune responses in the lungs. Future work should focus on understanding the enhancing effects of this combination on innate and adaptive immune pathways both locally and systemically.

Although retinoic acid contributes to various immune processes [67], excessive intake of VA can be toxic [68]; this creates an obstacle for the human application of VA consumption as a potential influenza preventative. The Non-Observed Adverse Effect Level and Lowest Observed Adverse Effect Level of VA have been reported as 6000 and 13,500 $\mu \mathrm{g} /$ day, respectively [69]. Based on the current study, it is estimated that $3690 \mu \mathrm{g} /$ day of VA equivalent dose in adult humans will be required [70]. While this amount is slightly higher than the upper recommended limit of VA for daily intake according to the National Institute of Health [71], a much lower dose of VA in combination with KB290 could be sufficient in the gut to show protection against seasonal influenza.

As a safer plan for humans, $\beta$-carotene is the most appropriate candidate for VA sources because it is a pro-VA present in plant-derived foods such as carrots and its efficiency for VA production in humans is thought to be regulated by an individual's VA status [72]. No serious side effects of $\beta$-carotene have been reported, except when a large amount of it was ingested as a supplement under high oxidative stress conditions, like smoking [73]. Therefore, it is considered as an ideal alternative to retinoic acid for human consumption. Further studies will be also required to establish the effective dose of VA in the form of $\beta$-carotene in combination with KB290 in humans.

In summary, the results presented here provide evidence for the efficacy of oral administration of the combination of heat-killed Lactobacillus brevis KB290 and VA for protecting mice against a sublethal dose of IAV. These findings suggest that the combination of KB290 and VA could be a useful food supplement to provide protection against seasonal influenza virus infections in humans.

Author Contributions: Conceptualisation, S.S. (Shohei Satomi), S.S. (Shigenori Suzuki), H.S., A.H., S.K.G.; methodology, S.S. (Shohei Satomi), S.K., A.H., S.K.G.; formal analysis, S.S. (Shohei Satomi), P.M., A.H., S.K.G.; investigation, S.S. (Shohei Satomi), S.K., A.H., S.K.G.; data curation, S.S. (Shohei Satomi), S.K., A.H., S.K.G.; writing-original draft preparation, S.S. (Shohei Satomi), A.H., S.K.G.; writing-review and editing, S.S. (Shohei Satomi), S.S. (Shigenori Suzuki), H.S., A.H., S.K.G.; visualisation, S.S. (Shohei Satomi), P.M., A.H., S.K.G.; supervision, S.S. (Shigenori Suzuki), A.H., S.K.G.; project administration, S.S. (Shigenori Suzuki), H.S.; funding acquisition, S.S. (Shohei Satomi), S.S. (Shigenori Suzuki), H.S. All authors have read and agreed to the published version of the manuscript.

Funding: This research received no external funding. 
Acknowledgments: We thank Jolon Dyer (AgResearch Ltd.) for assistance in the execution of this study. We also thank Katie Oakley, from Edanz Group (https://en-author-services.edanzgroup.com/) for editing a draft of this manuscript.

Conflicts of Interest: The authors declare no conflict of interest.

\section{References}

1. World Health Organization (WHO). Influenza (Seasonal). Available online: https://www.who.int/newsroom/fact-sheets/detail/influenza-(seasonal) (accessed on 18 March 2020).

2. Guillemard, E.; Tondu, F.; Lacoin, F.; Schrezenmeir, J. Consumption of a fermented dairy product containing the probiotic Lactobacillus casei DN-114001 reduces the duration of respiratory infections in the elderly in a randomised controlled trial. Br. J. Nutr. 2010, 103, 58-68. [CrossRef]

3. Gasparini, R.; Bonanni, P.; Amicizia, D.; Bella, A.; Donatelli, I.; Cristina, M.L.; Panatto, D.; Luigi Lai, P. Influenza epidemiology in Italy two years after the 2009-2010 pandemic need to improve vaccination coverage. Hum. Vaccin Immunother. 2013, 9, 561-567. [CrossRef] [PubMed]

4. Takeda, S.; Takeshita, M.; Kikuchi, Y.; Dashnyam, B.; Kawahara, S.; Yoshida, H.; Watanabe, W.; Muguruma, M.; Kurokawa, M. Efficacy of oral administration of heat-killed probiotics from Mongolian dairy products against influenza infection in mice: Alleviation of influenza infection by its immunomodulatory activity through intestinal immunity. Int. Immunopharmacol. 2011, 11, 1976-1983. [CrossRef] [PubMed]

5. Youn, H.-N.; Lee, D.-H.; Lee, Y.-N.; Park, J.-K.; Yuk, S.-S.; Yang, S.-Y.; Lee, H.-J.; Woo, S.-H.; Kim, H.-M.; Lee, J.-B.; et al. Intranasal administration of live Lactobacillus species facilitates protection against influenza virus infection in mice. Antivir. Res. 2012, 93, 138-143. [CrossRef] [PubMed]

6. Kawase, M.; He, F.; Kubota, A.; Yoda, K.; Miyazawa, K.; Hiramatsu, M. Heat-killed Lactobacillus gasseri TMC0356 protects mice against influenza virus infection by stimulating gut and respiratory immune responses. FEMS Immunol. Med. Microbiol. 2012, 64, 280-288. [CrossRef] [PubMed]

7. Kechaou, N.; Chain, F.; Gratadoux, J.-J.; Blugeon, S.; Bertho, N.; Chevalier, C.; Le Goffic, R.; Courau, S.; Molimard, P.; Chatel, J.M.; et al. Identification of one novel candidate probiotic Lactobacillus plantarum strain active against influenza virus infection in mice by a large-scale screening. Appl. Environ. Microbiol. 2013, 79, 1491-1499. [CrossRef]

8. Kiso, M.; Takano, R.; Sakabe, S.; Katsura, H.; Shinya, K.; Uraki, R.; Watanabe, S.; Saito, H.; Toba, M.; Kohda, N.; et al. Protective efficacy of orally administered, heat-killed Lactobacillus pentosus b240 against Influenza A virus. Sci. Rep. 2013, 3, 1563. [CrossRef]

9. Lee, Y.-N.; Youn, H.-N.; Kwon, J.-H.; Lee, D.-H.; Park, J.-K.; Yuk, S.-S.; Erdene-Ochir, T.-O.; Kim, K.-T.; Lee, J.-B.; Park, S.-Y.; et al. Sublingual administration of Lactobacillus rhamnosus affects respiratory immune responses and facilitates protection against Influenza virus infection in mice. Antivir. Res. 2013, 98, $284-290$. [CrossRef]

10. Park, M.-K.; Ngo, V.; Kwon, Y.-M.; Lee, Y.-T.; Yoo, S.; Cho, Y.-H.; Hong, S.-M.; Hwang, H.S.; Ko, E.-J.; Jung, Y.-J.; et al. Lactobacillus plantarum DK119 as a probiotic confers protection against influenza virus by modulating innate immunity. PLoS ONE 2013, 8, e75368. [CrossRef]

11. Park, S.; Kim, J.I.; Bae, J.-Y.; Yoo, K.; Kim, H.; Kim, I.-H.; Park, M.-S.; Lee, I. Effects of heat-killed Lactobacillus plantarum against Influenza viruses in mice. J. Microbiol. 2018, 56, 145-149. [CrossRef]

12. Kikuchi, Y.; Kunitoh-Asari, A.; Hayakawa, K.; Imai, S.; Kasuya, K.; Abe, K.; Adachi, Y.; Fukudome, S.-I.; Takahashi, Y.; Hachimura, S. Oral administration of Lactobacillus plantarum strain AYA enhances IgA secretion and provides survival protection against influenza virus infection in mice. PLoS ONE 2014, 9, e86416. [CrossRef] [PubMed]

13. Nakayama, Y.; Moriya, T.; Sakai, F.; Ikeda, N.; Shiozaki, T.; Hosoya, T.; Nakagawa, H.; Miyazaki, T. Oral administration of Lactobacillus gasseri SBT2055 is effective for preventing influenza in mice. Sci. Rep. 2014, 4, 4638. [CrossRef] [PubMed]

14. Waki, N.; Yajima, N.; Suganuma, H.; Buddle, B.M.; Luo, D.; Heiser, A.; Zheng, T. Oral administration of Lactobacillus brevis KB290 to mice alleviates clinical symptoms following influenza virus infection. Lett. Appl. Microbiol. 2014, 58, 87-93. [CrossRef] [PubMed] 
15. Belkacem, N.; Serafini, N.; Wheeler, R.; Derrien, M.; Boucinha, L.; Couesnon, A.; Cerf-Bensussan, N.; Gomperts Boneca, I.; Di Santo, J.P.; Taha, M.-K.; et al. Lactobacillus paracasei feeding improves immune control of influenza infection in mice. PLoS ONE 2017, 12, e0184976. [CrossRef]

16. Bae, J.-Y.; Kim, J.I.; Park, S.; Yoo, K.; Kim, I.-H.; Joo, W.; Ryu, B.H.; Park, M.S.; Lee, I.; Park, M.-S. Effects of Lactobacillus plantarum and Leuconostoc mesenteroides probiotics on Human Seasonal and Avian Influenza Viruses. J. Microbiol Biotechnol. 2018, 28, 893-901. [CrossRef]

17. Takahashi, E.; Sawabuchi, T.; Kimoto, T.; Sakai, S.; Kido, H. Lactobacillus delbrueckii ssp. bulgaricus OLL1073R-1 feeding enhances humoral immune responses, which are suppressed by the antiviral neuraminidase inhibitor oseltamivir in influenza A virus-infected mice. J. Dairy Sci. 2019, 102, 9559-9569. [CrossRef]

18. Ishibashi, N.; Yamazaki, S. Probiotics and safety. Am. J. Clin. Nutr. 2001, 73, 465s-470s. [CrossRef]

19. Liong, M.-T. Safety of probiotics: Translocation and infection. Nutr. Rev. 2008, 66, 192-202. [CrossRef]

20. Ouwehand, A.C.; Forssten, S.; Hibberd, A.A.; Lyra, A.; Stahl, B. Probiotic approach to prevent antibiotic resistance. Ann. Med. 2016, 48, 246-255. [CrossRef]

21. Hanchi, H.; Mottawea, W.; Sebei, K.; Hammami, R. The Genus Enterococcus: Between probiotic potential and safety concerns-an update. Front. Microbiol. 2018, 9, 1791. [CrossRef]

22. Piqué, N.; Berlanga, M.; Miñana-Galbis, D. Health benefits of Heat-Killed (Tyndallized) probiotics: An overview. Int. J. Mol. Sci. 2019, 20, 2534. [CrossRef]

23. Tanaka, Y.; Hirose, Y.; Yamamoto, Y.; Yoshikai, Y.; Murosaki, S. Daily intake of heat-killed Lactobacillus plantarum L-137 improves inflammation and lipid metabolism in overweight healthy adults: A randomized-controlled trial. Eur. J. Nutr. 2019. [CrossRef]

24. Warda, A.K.; Rea, K.; Fitzgerald, P.; Hueston, C.; Gonzalez-Tortuero, E.; Dinan, T.G.; Hill, C. Heat-killed lactobacilli alter both microbiota composition and behaviour. Behav. Brain Res. 2019, 362, 213-223. [CrossRef] [PubMed]

25. Li, N.; Russell, W.M.; Douglas-Escobar, M.; Hauser, N.; Lopez, M.; Neu, J. Live and Heat-Killed Lactobacillus rhamnosus GG: Effects on proinflammatory and anti-inflammatory Cytokines/Chemokines in gastrostomy-fed infant rats. Pediatr. Res. 2009, 66, 203-207. [CrossRef] [PubMed]

26. Sang, L.-X.; Chang, B.; Wang, B.-Y.; Liu, W.-X.; Jiang, M. Live and heat-killed probiotic: Effects on chronic experimental colitis induced by dextran sulfate sodium (DSS) in rats. Int. J. Clin. Exp. Med. 2015, 8, 20072-20078.

27. Ciandrini, E.; Campana, R.; Baffone, W. Live and heat-killed Lactobacillus spp. interfere with Streptococcus mutans and Streptococcus oralis during biofilm development on titanium surface. Arch. Oral Biol. 2017, 78, 48-57. [CrossRef]

28. Penkert, R.R.; Jones, B.G.; Häcker, H.; Partridge, J.F.; Hurwitz, J.L. Vitamin A differentially regulates cytokine expression in respiratory epithelial and macrophage cell lines. Cytokine 2017, 91, 1-5. [CrossRef]

29. Nobuta, Y.; Inoue, T.; Suzuki, S.; Arakawa, C.; Yakabe, T.; Ogawa, M.; Yajima, N. The efficacy and the safety of Lactobacillus brevis KB290 as a human probiotic. Int. J. Probio. Prebio. 2009, 4, 263-270.

30. Murakami, K.; Habukawa, C.; Nobuta, Y.; Moriguchi, N.; Takemura, T. The effect of Lactobacillus brevis KB290 against irritable bowel syndrome: A placebo-controlled double-blind crossover trial. Biopsychosoc. Med. 2012, 6, 16. [CrossRef]

31. Kishi, A.; Uno, K.; Matsubara, Y.; Okuda, C.; Kishida, T. Effect of the oral administration of Lactobacillus brevis subsp. coagulans on interferon-alpha producing capacity in humans. J. Am. Coll. Nutr. 1996, 15, 408-412. [CrossRef]

32. Fukui, Y.; Sasaki, E.; Fuke, N.; Nakai, Y.; Ishijima, T.; Abe, K.; Yajima, N. Effect of Lactobacillus brevis KB290 on the cell-mediated cytotoxic activity of mouse splenocytes: A DNA microarray analysis. Br. J. Nutr. 2013, 2, 1-13. [CrossRef] [PubMed]

33. Waki, N.; Matsumoto, M.; Fukui, Y.; Suganuma, H. Effects of probiotic Lactobacillus brevis KB290 on incidence of influenza infection among schoolchildren: An open-label pilot study. Lett. Appl. Microbiol. 2014, 59, 565-571. [CrossRef] [PubMed]

34. Long, K.Z.; García, C.; Santos, J.I.; Rosado, J.L.; Hertzmark, E.; DuPont, H.L.; Ko, G. Vitamin A supplementation has divergent effects on norovirus infections and clinical symptoms among Mexican children. J. Infect. Dis. 2007, 196, 978-985. [CrossRef] [PubMed] 
35. Long, K.Z.; Garcia, C.; Ko, G.; Santos, J.I.; Al Mamun, A.; Rosado, J.L.; DuPont, H.L.; Nathakumar, N. Vitamin A modifies the intestinal chemokine and cytokine responses to norovirus infection in Mexican children. J. Nutr. 2011, 141, 957-963. [CrossRef]

36. Hall, J.A.; Cannons, J.L.; Grainger, J.R.; Dos Santos, L.M.; Hand, T.W.; Naik, S.; Wohlfert, E.A.; Chou, D.B.; Oldenhove, G.; Robinson, M.; et al. Essential role for retinoic acid in the promotion of CD4(+) T cell effector responses via retinoic acid receptor alpha. Immunity 2011, 34, 435-447. [CrossRef]

37. Oliveira, L.M.; Teixeira, F.; Sato, M.N. Impact of retinoic acid on immune cells and inflammatory diseases. Mediat. Inflamm. 2018, 2018, 3067126. [CrossRef]

38. Svensson, M.; Johansson-Lindbom, B.; Zapata, F.; Jaensson, E.; Austenaa, L.M.; Blomhoff, R.; Agace, W.W. Retinoic acid receptor signaling levels and antigen dose regulate gut homing receptor expression on CD8+ T cells. Mucosal Immunol. 2008, 1, 38-48. [CrossRef]

39. Zeng, R.; Oderup, C.; Yuan, R.; Lee, M.; Habtezion, A.; Hadeiba, H.; Butcher, E.C. Retinoic acid regulates the development of a gut-homing precursor for intestinal dendritic cells. Mucosal Immunol. 2013, 6, 847-856. [CrossRef]

40. Bakdash, G.; Vogelpoel, L.T.; van Capel, T.M.; Kapsenberg, M.L.; de Jong, E.C. Retinoic acid primes human dendritic cells to induce gut-homing, IL-10-producing regulatory T cells. Mucosal Immunol. 2015, 8, 265-278. [CrossRef]

41. Matsumiya, T.; Stafforini, D.M. Function and regulation of retinoic acid-inducible gene-I. Crit. Rev. Immunol. 2010, 30, 489-513. [CrossRef]

42. Lee, H.; Ko, G. Antiviral effect of vitamin A on norovirus infection via modulation of the gut microbiome. Sci. Rep. 2016, 6, 25835. [CrossRef] [PubMed]

43. Surman, S.L.; Jones, B.G.; Sealy, R.E.; Rudraraju, R.; Hurwitz, J.L. Oral retinyl palmitate or retinoic acid corrects mucosal IgA responses toward an intranasal influenza virus vaccine in vitamin A deficient mice. Vaccine 2014, 32, 2521-2524. [CrossRef] [PubMed]

44. Cottey, R.; Rowe, C.A.; Bender, B.S. Influenza Virus. Curr. Protoc. Immunol. 2001, 42, 19.11.1-19.11.32. [CrossRef] [PubMed]

45. Eisfeld, A.J.; Neumann, G.; Kawaoka, Y. Influenza a virus isolation, culture and identification. Nat. Protoc. 2014, 9, 2663-2681. [CrossRef]

46. Mei, J.; Riedel, N.; Grittner, U.; Endres, M.; Banneke, S.; Emmrich, J.V. Body temperature measurement in mice during acute illness: Implantable temperature transponder versus surface infrared thermometry. Sci. Rep. 2018, 8, 3526. [CrossRef]

47. Kawase, M.; He, F.; Kubota, A.; Harata, G.; Hiramatsu, M. Oral administration of lactobacilli from human intestinal tract protects mice against influenza virus infection. Lett. Appl. Microbiol. 2010, 51, 6-10. [CrossRef]

48. Barfod, K.K.; Roggenbuck, M.; Hansen, L.H.; Schjørring, S.; Larsen, S.T.; Sørensen, S.J.; Krogfelt, K.A. The murine lung microbiome in relation to the intestinal and vaginal bacterial communities. BMC Microbiol. 2013, 13, 303. [CrossRef]

49. Pritzl, C.J.; Seo, Y.-J.; Xia, C.; Vijayan, M.; Stokes, Z.D.; Hahm, B. A ceramide analogue stimulates dendritic cells to promote T cell responses upon virus infections. J. Immunol. 2015, 194, 4339-4349. [CrossRef]

50. Wood, S.N. Fast stable restricted maximum likelihood and marginal likelihood estimation of semiparametric generalized linear models. J. R. Stat. Soc. 2011, 73, 3-36. [CrossRef]

51. Lenth, R.; Buerkner, P.; Herve, M.; Love, J.; Riebl, H.; Singmann, H. Emmeans: Estimated Marginal Means, aka Least-Squares Means, R Package Version 1.4.8. 2020. Available online: https://CRAN.R-project.org/ package $=$ emmeans (accessed on 21 September 2020).

52. Benjamini, Y.; Hochberg, Y. Controlling the false discovery rate: A practical and powerful approach to multiple testing. J. R. Stat. Soc. 1995, 57, 289-300. [CrossRef]

53. Drummond, G.B.; Vowler, S.L. Different tests for a difference: How do we do research? J. Physiol. 2012, 590, 235-238. [CrossRef] [PubMed]

54. Ludbrook, J.; Dudley, H. Why permutation tests are superior to T and F tests in biomedical research. Am. Stat. 1998, 52, 127-132. [CrossRef]

55. Maxime, H. RVAideMemoire: Testing and Plotting Procedures for Biostatistics. R Package Version 0.9-77. 2020. Available online: https://CRAN.R-project.org/package=RVAideMemoire (accessed on 21 September 2020).

56. Sun, K.; Torres, L.; Metzger, D.W. A detrimental effect of Interleukin-10 on protective pulmonary humoral immunity during primary Influenza A virus infection. J. Virol. 2010, 84, 5007-5014. [CrossRef] [PubMed] 
57. Langlois, R.A.; Legge, K.L. Plasmacytoid dendritic cells enhance mortality during lethal influenza infections by eliminating virus specific CD8 T Cells. J. Immunol. 2010, 184, 4440-4446. [CrossRef]

58. Pang, I.K.; Pillai, P.S.; Iwasaki, A. Efficient influenza A virus replication in the respiratory tract requires signals from TLR7 and RIG-I. Proc. Natl. Acad. Sci. USA 2013, 110, 13910-13915. [CrossRef]

59. Keef, E.; Zhang, L.A.; Swigon, D.; Urbano, A.; Ermentrout, G.B.; Matuszewski, M.; Toapanta, F.R.; Ross, T.M.; Parker, R.S.; Clermont, G. Discrete dynamical modeling of influenza virus infection suggests age-dependent differences in immunity. J. Virol. 2017, 91, e00395-e00417. [CrossRef]

60. Brandes, M.; Klauschen, F.; Kuchen, S.; Germain, R.N. A systems analysis identifies a feedforward inflammatory circuit leading to lethal influenza infection. Cell 2013, 154, 197-212. [CrossRef]

61. Kumova, O.K.; Fike, A.J.; Thayer, J.L.; Nguyen, L.T.; Mell, J.C.; Pascasio, J.; Stairiker, C.; Leon, L.G.; Katsikis, P.D.; Carey, A.J. Lung transcriptional unresponsiveness and loss of early influenza virus control in infected neonates is prevented by intranasal Lactobacillus rhamnosus GG. PLoS Pathog. 2019, 15, e1008072. [CrossRef]

62. Goto, H.; Sagitani, A.; Ashida, N.; Kato, S.; Hirota, T.; Shinoda, T.; Yamamoto, N. Anti-influenza virus effects of both live and non-live Lactobacillus acidophilus L-92 accompanied by the activation of Innate immunity. Br. J. Nutr. 2013, 110, 1810-1818. [CrossRef]

63. Jung, Y.-J.; Lee, Y.-T.; Ngo, V.L.; Cho, Y.-H.; Ko, E.-J.; Hong, S.-M.; Kim, K.-H.; Jang, J.-H.; Oh, J.-S.; Park, M.-K.; et al. Heat-killed Lactobacillus casei confers broad protection against influenza A virus primary infection and develops heterosubtypic immunity against future secondary infection. Sci. Rep. 2017, 7, 17360. [CrossRef]

64. Nagai, T.; Makino, S.; Ikegami, S.; Itoh, H.; Yamada, H. Effects of oral administration of yogurt fermented with Lactobacillus delbrueckii ssp. bulgaricus OLL1073R-1 and its exopolysaccharides against influenza virus infection in mice. Int. Immunopharmacol. 2011, 11, 2246-2250. [CrossRef] [PubMed]

65. Zelaya, H.; Tada, A.; Vizoso-Pinto, M.G.; Salva, S.; Kanmani, P.; Aguero, G.; Alvarez, S.; Kitazawa, H.; Villena, J. Nasal priming with immunobiotic Lactobacillus rhamnosus modulates inflammation-coagulation interactions and reduces influenza virus-associated pulmonary damage. Inflamm. Res. 2015, 64, 589-602. [CrossRef] [PubMed]

66. Sasaki, E.; Suzuki, S.; Fukui, Y.; Yajima, N. Cell-bound exopolysaccharides of Lactobacillus brevis KB290 enhance cytotoxic activity of mouse splenocytes. J. Appl. Microbiol. 2015, 118, 506-514. [CrossRef] [PubMed]

67. Pino-Lagos, K.; Guo, Y.; Noelle, R.J. Retinoic acid: A key player in immunity. Biofactors 2010, 36, 430-436. [CrossRef] [PubMed]

68. Hathcock, J.N.; Hattan, D.G.; Jenkins, M.Y.; McDonald, J.T.; Sundaresan, P.R.; Wilkening, V.L. Evaluation of Vitamin A toxicity. Am. J. Clin. Nutr. 1990, 52, 183-202. [CrossRef] [PubMed]

69. Gerald, Y.M.; James, K.K.; Wei-Sek, H. Vitamin A hepatotoxicity in multiple family members. Hepatology 1988, 8, 272-275. [CrossRef]

70. Anroop, B.N.; Shery, J. A simple practice guide for dose conversion between animals and human. J. Basic Clin. Pharm. 2016, 7, 27-31. [CrossRef]

71. National Institute of Health (NIH). Vitamin A. Available online: https://ods.od.nih.gov/factsheets/VitaminAConsumer/ (accessed on 14 September 2020).

72. Lobo, G.P.; Hessel, S.; Eichinger, A.; Noy, N.; Moise, A.R.; Wyss, A.; Palczewski, K.; Lintig, J.V. ISX is a retinoic acid-sensitive gatekeeper that controls intestinal beta, beta-carotene absorption and vitamin A production. Fed. Am. Soc. Exp. Biol. J. 2010, 24, 1656-1666. [CrossRef]

73. Goodman, G.E.; Thornquist, M.D.; Balmes, J.; Cullen, M.R.; Meyskens, F.L., Jr.; Omenn, G.S.; Valanis, B.; Williams, J.H., Jr. The Beta-Carotene and Retinol Efficacy Trial: Incidence of lung cancer and cardiovascular disease mortality during 6-year follow-up after stopping Beta-Carotene and Retinol Supplements. J. Natl. Cancer Inst. 2004, 96, 1743-1750. [CrossRef]

(C) 2020 by the authors. Licensee MDPI, Basel, Switzerland. This article is an open access article distributed under the terms and conditions of the Creative Commons Attribution (CC BY) license (http://creativecommons.org/licenses/by/4.0/). 